\title{
Techno-Economic Analysis of Solar Powered Water Pumping System
}

\author{
Rakhi Sharma, Shivanshu Sharma, Shashank Sharma
}

\begin{abstract}
Analytical study of solar photovoltaic water pumping system can be performed on the basis of technical, economical and environmental phenomenon. Use of solar energy to generate off grid electric power has been enhanced in these days and it is continuously increasing day to day due to the active interest of government and people. Numbers of applications are available in the solar energy field and amongst its various applications solar photovoltaic water pumping system is best utilized for agriculture and community water supply. It has increased agriculture productivity due to the power availability when needed for irrigation. This technology has improved the living standard of farmers and villagers who have not proper electrical supply as per their requirement for water pumping. This technology is helping to complete the mission of government and helps farmers to get water pumping system without any need of grid connection. The use of fossil fuels was common earlier for the pumping system and mostly diesel generator based systems are used which causes emission of $\mathrm{CO} 2$ and other harmful gases. Fossil fuels increase pollution and causes global warming, health problems and many more while solar energy based applications are helping to reduce CO2 emission and making a step toward green environment. This manuscript presents study of technical and economic analysis of solar water pumping system useful for various water supply applications especially in agriculture sector.
\end{abstract}

Keywords: Solar Water Pumping System, Irrigation, Present Worth, Payback Period, Performance Analysis, Photovoltaic (PV), Cost comparison.

\section{INTRODUCTION}

Most of the population in developing and poor nations experiences poor water benefits. Farmers are completely dependent on conflicting rainfall and groundwater to satisfy irrigation need of their yields.The source of energy to pump water is a major issue in developing nations. Building up a grid network is very expensive in remote areas. Availability of fuel is also an option for water pumping but transportation cost in remote areas makes it very difficult to choose for farmers. Best option for this is renewable energy sources like solar, wind, hydroelectric, Biomass etc.

Revised Manuscript Received on December 20, 2019.

* Correspondence Author

Rakhi Sharma, School of Engineering \& Technology, Indira Gandhi National Open University, Delhi, IndiaEmail:rakhis_ignou@rediffmail.com

Shivanshu Sharma, Uttar Pradesh Power Corporation Ltd. Delhi, India Email: shivanshugecj@gmail.com

Shashank Sharma*, Madhav Institute of Technology \& Science (MITS) Gwalior, M.P, India. Email: shashank56786@ gmail.com

(C) The Authors. Published by Blue Eyes Intelligence Engineering and Sciences Publication (BEIESP). This is an open access article under the CC BY-NC-ND license (http://creativecommons.org/licenses/by-nc-nd/4.0/)
Among these all solar energy is most suitable for irrigation application. There are numerous applications of solar energy like solar pumping system, grid connected system, solar street lights and as solar thermal in heating and industrial processes. Solar photovoltaic panels are used which convert freely available solar energy into direct current (DC) electricity and further this DC supply is used to fulfill the power demand of the system.

\section{A. About solar energy}

Solar energy is accessible in plenitude in most parts of the world. The measure of solar energy incident on the world's surface is approximately $1.5 \times 10^{18} \mathrm{kWh} /$ year, which is around 10,000 times the present yearly energy utilization of the whole world. The density of power transmitted from the sun (known as solar energy constant) is $1.373 \mathrm{~kW} / \mathrm{m}^{2}$. The smallest unit used to convert solar energy into DCs power is known as solar cell. A solar cell is made from different $P$ and $\mathrm{N}$ type semiconductors. The solar cells are connected in series and parallel to obtain adequate power and this arrangement is known as $\mathrm{PV}$ module. As per requirement number of PV modules are connected to generate more power and form a PV array. The temperature, solar insolation, wind velocity etc. are some environmental parameters that can affect the energy generation and performance of the system.

\section{B. Solar photovoltaic water pumping system}

To pump the water without any need of grid connection or fossil fuels, solar photovoltaic (PV) modules are used to produce power supply for water pumping application. The system uses this power supply to operate all interconnected component of the system like motor, pump, controller unit etc. In direct-current (DC) operated pump the power supply is directly used but in alternating-current (AC) operated pump inverter unit is used to convert PV array generated DC into AC. When pump is not in operating state, the excess energy can be stored using batteries. A pump controlling unit is used to control all functionalities. At present remote monitoring system is also being used to monitor the pumping system from remote location based client server system. The major applications of solar photovoltaic water pumping system are irrigation, village water supply and livestock watering.

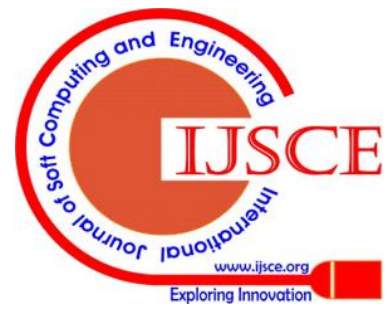




\section{LITERATURE REVIEW}

In the most recent couple of years, various investigations have given on solar photovoltaic water pumping system. Solar water pumps can give simple and economical water pumping choices for farmers to fulfill the water demand in remote areas. In this segment, the survey of various works identified which is related to solar PV water pumping system and various parameters in view of technical and economical investigation.

The study for performance analysis of solar photovoltaic water pumping system can be performed based on technical, economical and environmental phenomenon [1]. This is best application for water pumping for irrigation and community drinking water supplies. The number of innovations, research works have completed around the world for advancement of this technology [2]. The results based on resent researches show that the performance of the system is enhanced as it was earlier [3]. The new products with advanced technology have made system more productive with higher power yield. The cost of these products is economical and due to this it became easy to adopt for farmers [4].

The PV water pumping system is suitable solution for remote areas where grid connectivity is not available [5]. The demand of water supply is increased but the facilities are still not such to fulfill the demand. In remote areas the facilities are limited to get the water for different application and there solar PV water pumping is only the solution for water pumping [6]. The site selection is also an important parameter to consider during installation of pump. It helps to get the optimal performance from pumping system [7]. The subsidy given from government made the system economical for farmers but the economic viability changes when the size of the system in increased. The cost of the system will vary when the size of the system will enhanced from small scale application to the large scale application [8]. If the cost of the system will high then farmers will avoid using these systems. Attraction of people towards new technology in developing countries like India is only possible if manufacturer will provide low cost system with high quality [9].

Different methods are used to check the performance of the pumping system. The design optimization with numerical models is used to verify the system performance [10]. Monthly and yearly data are used to measure the long term performance of the system. This helps to get optimum system parameters which helps to enhance the water output of the system [11]. Loss of power supply probability (LPSP) concept is used to define optimal sizing of photovoltaic pumping system with water tank storage. Quality assessment can be performed using LPSP with taking LCC (life cycle cost) in consideration [12]. Performance of the PV modules depends on temperature and it will reduce at higher temperature [13]. Economic optimization of solar photovoltaic water pumping system can decline the capital cost up to $18.8 \%$ [14]. The cost of the controlling unit mainly known as pump controller or SPCU unit affects the total cost of the system. The economical pump controller with optimal performance can help to reduce the cost of the system [15]. The performance of the directly coupled photovoltaic pumping system with dc motor can be analyzed with the help of graphs showing variation in voltage-current and pump shaft torque-speed [16].The head size affects the water output of the pumping system. To get the desired output the head size should be low. The system with lower head size gives higher water output [17]. The effect of head size on water output can be analyzed by considering two systems with different head size and same design parameters. The result of this examination will help to analyze the effect of head size on system performance [18]. The water yield of the system is directly related to system size. As the size of the system will increased it will boost up the water yield but design parameters should be kept in consideration [19]. The system with hybrid power resources like solar and wind power generation can be used where both energy sources are available. The main drawback of this hybrid system is higher cost which makes it limited for certain places [20]. The best approach of sizing the system is theoretical designing followed by simulation using software. The number of software is available, which provides platform to analyze the system with variation in parameters. This helps to get optimum value of all parameter and improve the system performance [21].

\section{ANALYSIS OF SOLAR PHOTOVOLTAIC WATER PUMPING SYSTEM}

\section{A. Technical Analysis}

1. Element of solar photovoltaic water pumping system:In solar photovoltaic water pumping system to operate the pump set and pump controller requirement of power is fulfilled by PV array.

The Equipment/materials mainly used in solar photovoltaic water pumping system are -

- Solar PV Modules/Array

- AC/ DC Motor Pump set

- Mounting Structure and Tracking System

- Controller Unit (SPCU/ charge controller/ pump controller)

- Earthing/grounding unit

- Others (Pipe, rope, cables etc.).

PV Array: When solar cells are connected together it forms a PV module and when PV modules are connected together in an array forms PV array. The series combination of PV panels/modules increases the voltage and the parallel combination increases the current.

When solar radiation strikes on the solar cell it converts the solar radiation into DC (Direct Current). This effect is also known as photovoltaic effect.

In Series combination of solar cells total voltage will be added as $\mathrm{V}_{\mathrm{T}}=\mathrm{V}_{1}+\mathrm{V}_{2}+\mathrm{V}_{3}+\mathrm{V}_{4}+$ ... and current will be constant.

Parallel combination of solar cells total current will be added

Blue Eyes Intelligence Engineering

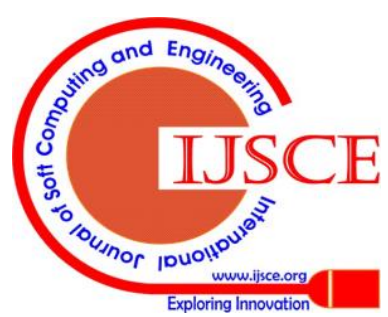

\& Sciences Publication

(c) Copyright: All rights reserved. 
as $\mathrm{I}_{\mathrm{T}}=\mathrm{I}_{1}+\mathrm{I}_{2}+\mathrm{I}_{3}+\mathrm{I}_{4}+\ldots \ldots$. and voltage will be constant.

Motor pump set: Motor pump set is used to move fluid using mechanical pressure created by it. In solar water pumping system, water is pumped using motor pumpset from water source to water collection unit or network of pipes for irrigation. The flow of the water can be controlled using controlling unit.

Mounting structure and tracking system: The PV modules are placed on a mechanical structure which is known as mounting structure. This movement of this mounting structure can be done either by manual or automatic and this process is known as tracking. In automatic tracking electronic controlling unit is used for solar panel/array movement and it move by tracking the sun direction using the sensors connected in it. This tracking can be made as seasonal or daily on daily basis. In seasonal tracking the mounting track is required to move in 3-4 month but in daily tracking in every 2-3 hour it is required to change the direction of mounting track. Tracking increases the output of the PV modules because it captures more energy by keeping module in direction of sun.

Controller Unit: - All system controls functions are completed by controller unit. The input power from PV array is varied and controlled by controller. The controller output is given as input power to system and matches the power level that the pump requires. It can control low voltage threat by voltage regulation. The water flow rate of pump is also controlled by this unit. It reduces the maintenance and increases the life span of system. If the system has the AC submersible pumping unit then solar power conditioning unit (SPCU) is used to control various factions for system and mainly convert dc power from solar panel to AC power as per AC pump requirement.

Earthing or Grounding unit - Earthing is necessary to take necessary measures to get the protection from high voltage shock hazard. Different types of earthing processes are used such as rod earthing, plate earthing, etc.

- Other materials- Pipes, ropes, cables etc. are some materials which are required in solar photovoltaic water pumping system installation.

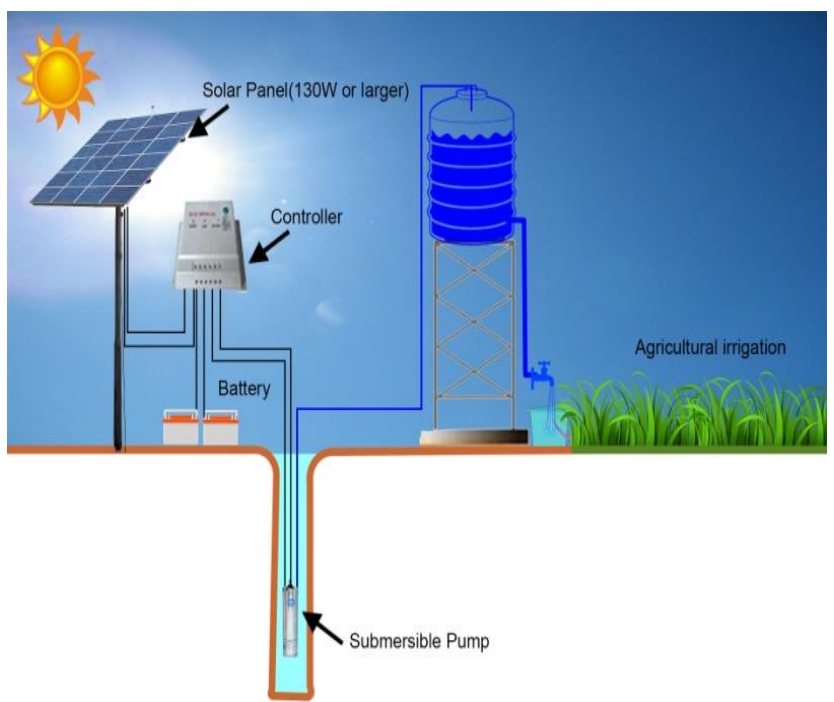

Fig. 1. Solar PV water pumping system

2. Flow diagram of solar photovoltaic water pumping system working

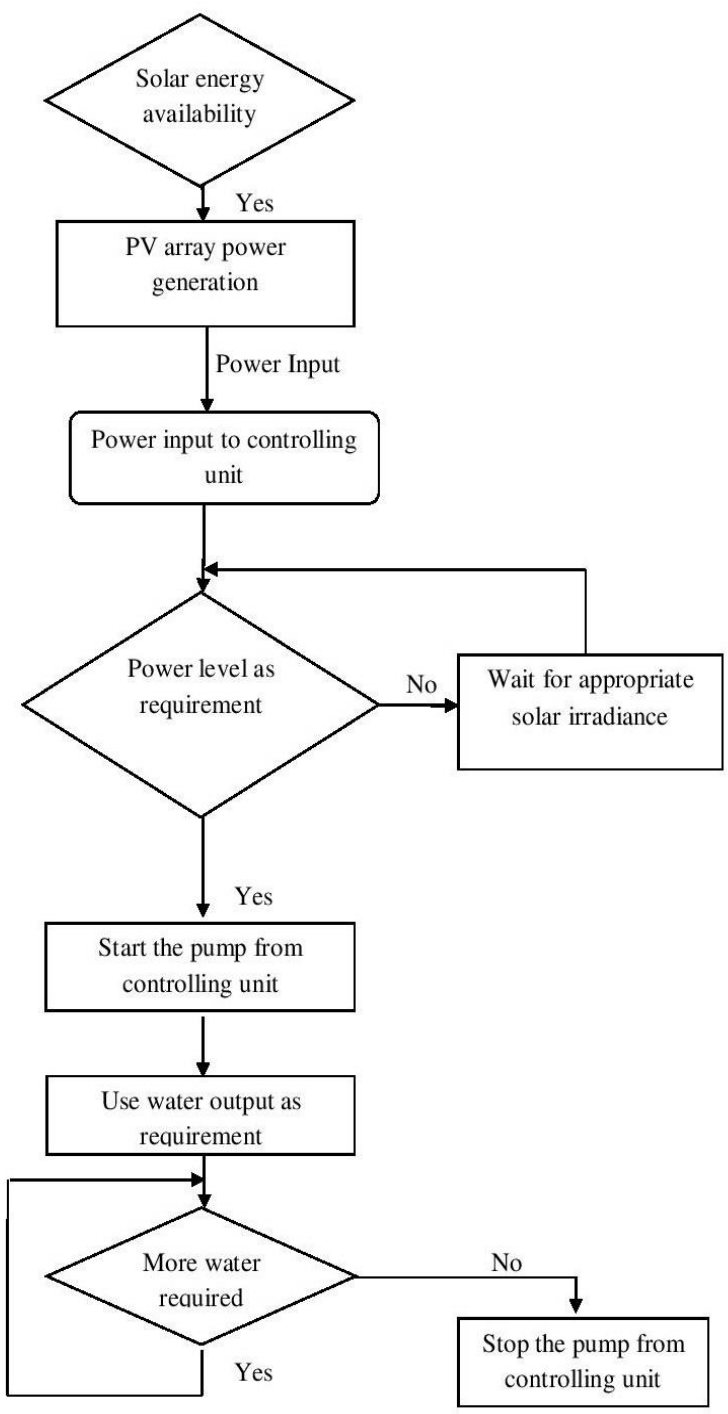

Fig. 2. Working of water pumping system 
3. Technical terms used in solar PV water pumping system

1) Flow: It is the rate at which water is delivered by pump and measured in liters/second or cubic meter per hour.

2) Volume: It is the total amount of water which is required daily and measured in cubic meters/day.

3) Suction Head: Vertical distance from surface of water to center of pump, when pump is located above water.

4) Discharge Head: Discharge head is the vertical distance from the center of pump to surface of storage tank, water or point of free charge.

5) Static Head: It is the vertical distance from surface of water to surface of storage tank water or point of free discharge.

Static Head= Suction Head + Discharge Head

6) Pressure Head: If a final discharge pressure is desired, the pump must be able to supply the flow with the needed energy. The pressure head is the equivalent meter of head the pump needs to be able to pump to supply this final pressure.

7) Friction Head: It is the equivalent distance for which the pump must be able to push water to have enough energy to overcome losses.

8) Draw Down: It is the distance from the surface of the water when it is being pumped to the surface level when it is static.

9) Total Dynamic Head = Suction Head + Discharge Head + Pressure Head+ Friction Head+ Draw Down [22]

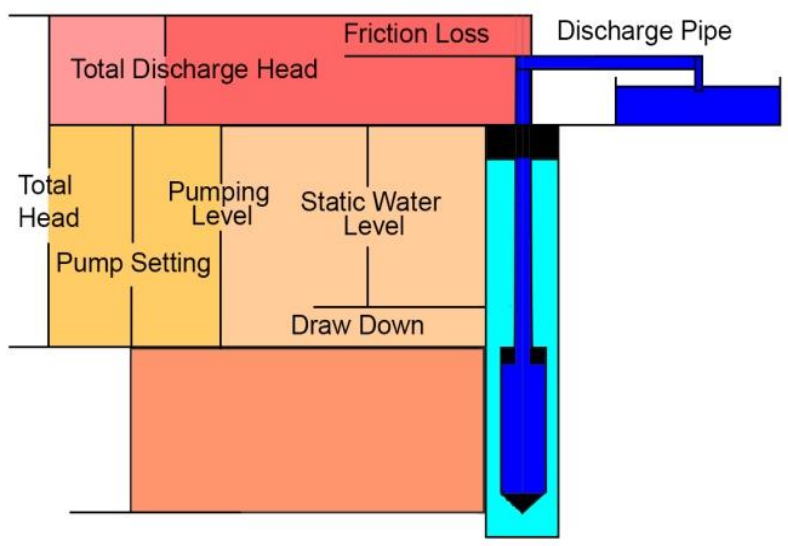

Fig. 3. Water level description for solar water pumping system

4. Classification of solar photovoltaic water pumping system

(i) Based on energy storage capacity- In this category system may be of two types - system with or without battery. In the system with battery ,. We can understand this using block diagram given below-

System with battery -

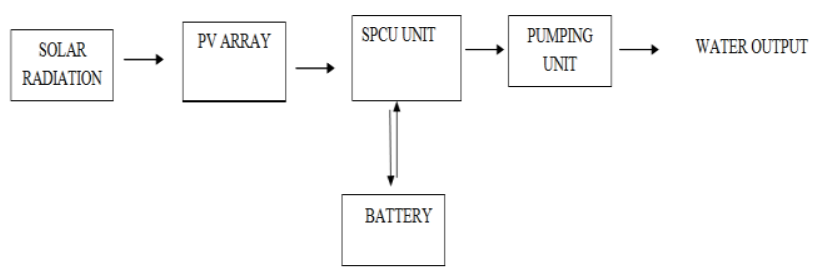

Fig. 4. Block diagram of system with battery System without battery -

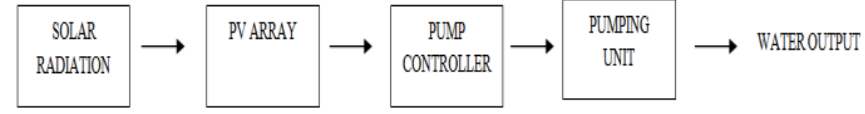

Fig. 5. Block diagram of system without battery

(ii) Based on pumping unit- In this category system submersible pumping unit may work on DC or AC current. In system with AC submersible pumping unit, Solar power control unit( SPCU) is used which may integrate number of components such as inverter to convert DC supply into AC supply, charge controller/ pump controller ,battery ,MPTT etc to control all other functionalities of pump set. In DC submersible pumping unit, there is no need of DC to AC current conversion so the pump controller (DC-DC) / charge controller control pumping system.

(iii) System with AC submersible pumping unit -

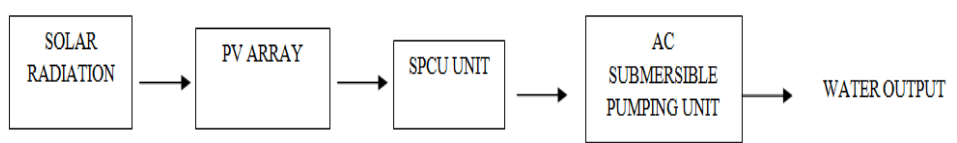

Fig. 6. Block diagram of system with AC submersible pumping unit

(iv) System with DC submersible pumping unit -

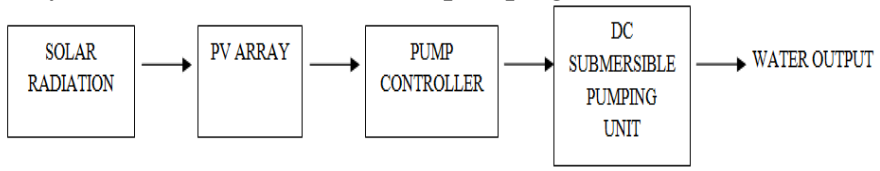

Fig. 7. Block diagram of system with DC submersible pumping unit

5. Effect of head size on water output of solar PV water pumping system-

In this part of study, comparison is done between water output and head size of same capacity system with different pumpset designs like AC and DC.

Head Size v/s water output in different size AC and DC submersible pumpset-

(i) $1 \mathrm{hp}\left(1200 \mathrm{~W}_{\mathrm{p}}\right) \mathrm{DC}$ and AC pumpset-

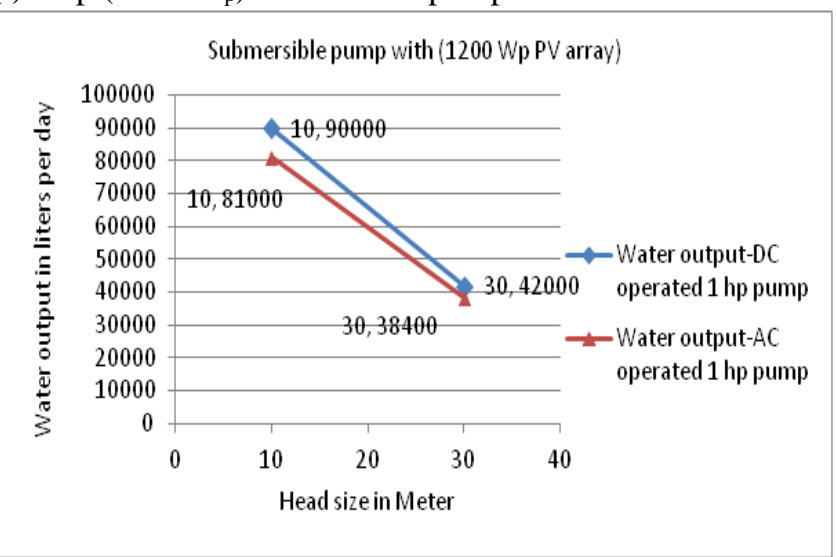

Fig. 8. Water output comparison in DC and AC 1 hp pump set at same Head size

Published By:

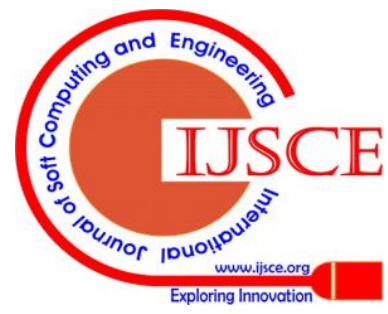


(ii) $3 \mathrm{hp}\left(3000 \mathrm{~W}_{\mathrm{p}}\right) \mathrm{DC}$ and AC pumpset-

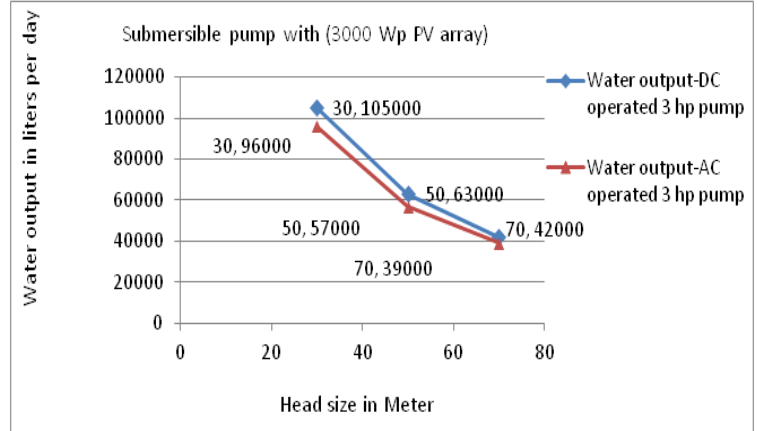

Fig. 9. Water output comparison in DC and AC 3 hp pump set at same Head size

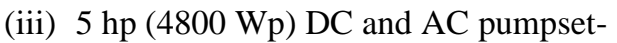

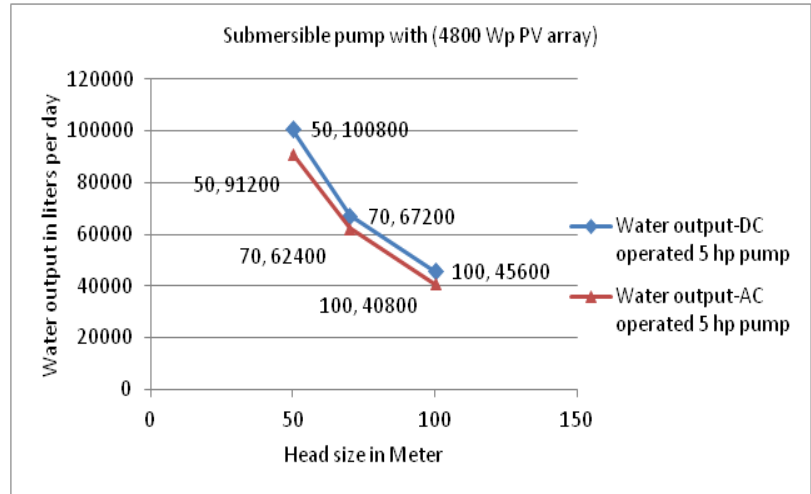

Fig. 10. Water output comparison in DC and AC 5 hp pump set at same Head size

(iv) $7.5 \mathrm{hp} \mathrm{(6750} \mathrm{Wp)} \mathrm{DC} \mathrm{and} \mathrm{AC} \mathrm{pumpset-}$

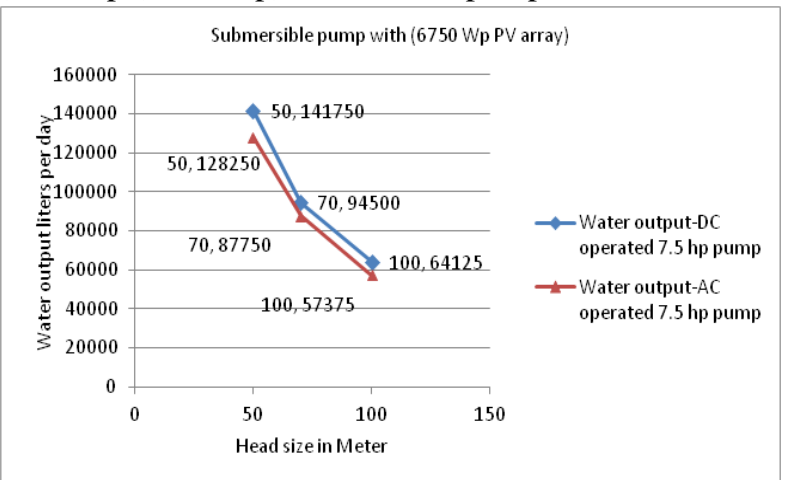

Fig. 11. Water output comparison in DC and AC 7.5 hp pump set at same Head size

(v) $10 \mathrm{hp}(9000 \mathrm{Wp}) \mathrm{DC}$ and AC pumpset-

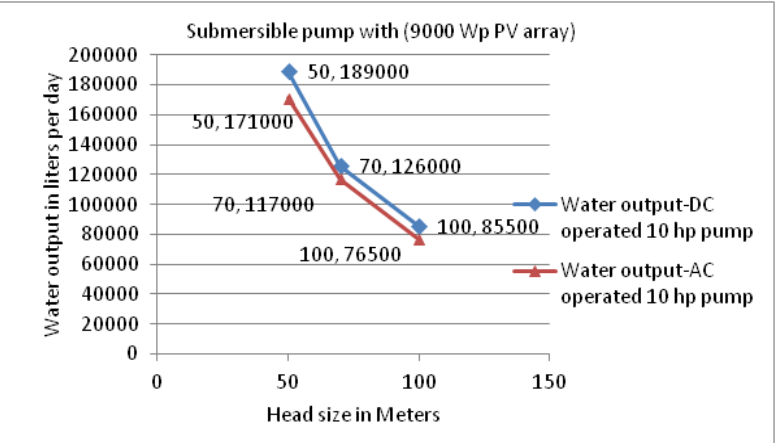

Fig. 12. Water output comparison in DC and AC $10 \mathrm{hp}$ pump set at same Head size

* figures indicate water output on a clear sunny day with

Retrieval Number:E3343019520/2020@BEIESP

DOI:10.35940/ijsce.E3343.019520

Journal Website: www.ijsce.org three times tracking of solar PV panel, and "Average Daily Solar Radiation" condition of $7.15 \mathrm{KWh} / \mathrm{m}^{2}$. on the surface of PV array (i.e. coplanar with the PV Modules).In the above graphs comparison result shows that water output decreases when head size is increases. The lower value of total head size gives higher water output. The water output for DC system is more than the water output of AC system.

\section{Technical analysis of practically reviewed system}
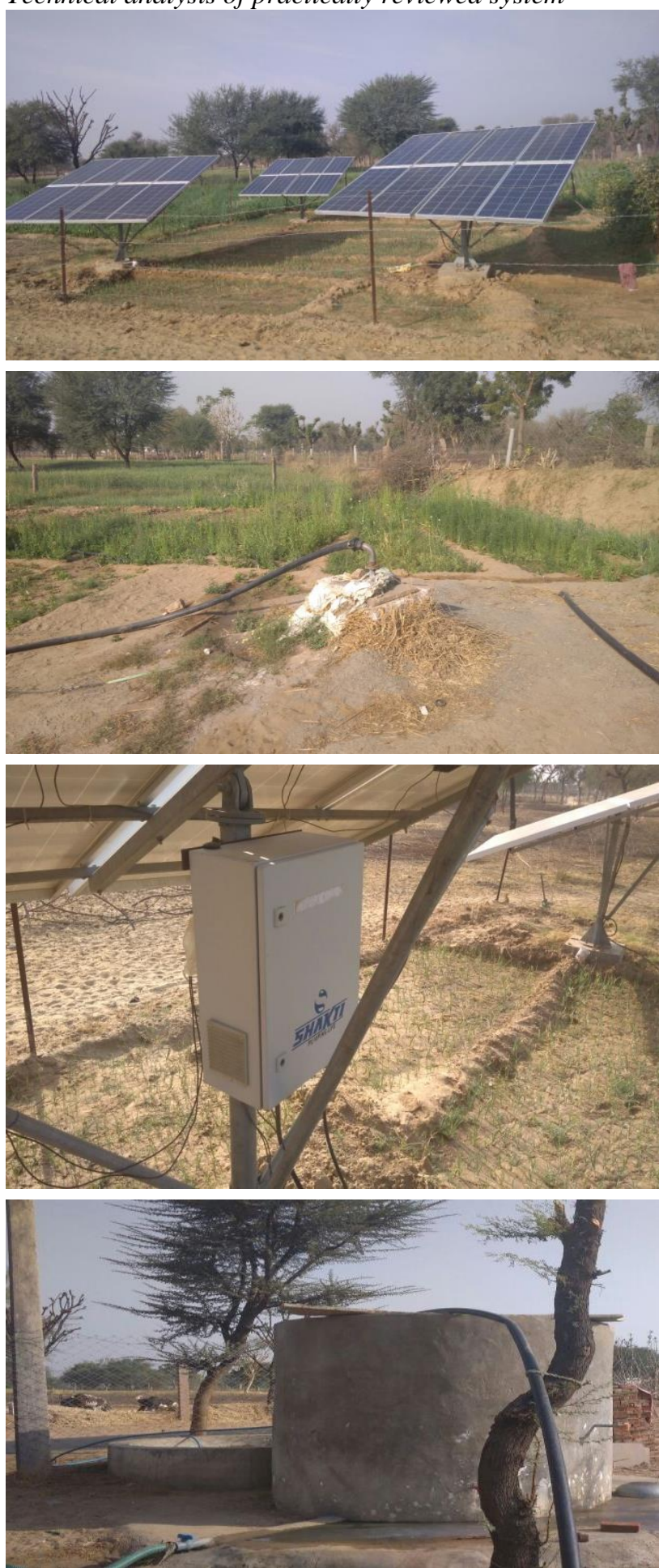

Fig. 13. Solar PV water pumping system installed at Jaipur (Rajasthan)

Published By:

Blue Eyes Intelligence Engineering \& Sciences Publication

C) Copyright: All rights reserved.

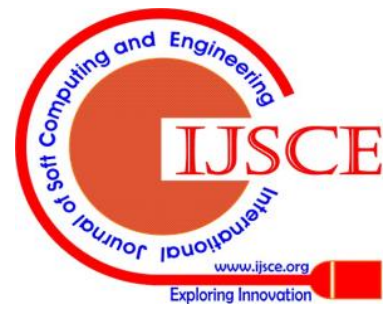


Table 1 Technical specification of solar PV water pumping system

\begin{tabular}{|l|l|}
\hline Name of location- & Karansar, Jaipur(Rajasthan) \\
\hline Users need- (Name of application)- & For agriculture, livestock watering, Water supply \\
\hline Name of manufacturer - & Shakti solar pump Pvt. ltd. \\
\hline Daily water requirement - & 50000 liters per day \\
\hline Name of water resource available - & Borewell \\
\hline Type of pump- & DC submersible pump \\
\hline Capacity of pump-(in HP) & 5 hp \\
\hline Phase of pump - & 3 phase \\
\hline Type of motor- & DC motor \\
\hline Type of pipe used- & Plastic pipes are used to connect borewell to water storage unit. \\
\hline Ground mounted/pole mounted structure & Pole mounted structure \\
\hline System is with or without tracking- & With tracking \\
\hline Material of mounting tracks- & G.I. made rods and sheets \\
\hline Information about Pump controller & Manufactured by the shakti solar pump pvt. ltd. \\
\hline Manufacturer of PV module / country & India \\
\hline Solar cell technology- & polycrystalline solar cell \\
\hline Rating of module- & 150 Wp \\
\hline Number of solar modules/panel & 32 \\
\hline
\end{tabular}

\section{Performance analysis of solar PV water pumping system}

Conversion efficiency (wire to water pumping) = Energy contained in output pumped water / Required input electrical energy from PV array

Daily average efficiency of motor pump set $\mathrm{X}$ dc to ac conversion $=0.35 \mathrm{X} 0.8=28 \%$

Additional losses $=5 \%$

So modified wire to water efficiency $=0.28(1-0.5)=$ $26.6 \%$

Energy contained in output pumped water:

Hydraulic energy $\mathrm{E}$ (in $\mathrm{kWh} / \mathrm{d}$ ) which is potential energy required in raising the water to discharge level. required per day to supply a volume $\mathrm{V}\left(\mathrm{m}^{3}\right)$ of water at total dynamic head $\mathrm{TDH}(\mathrm{m})$ is expressed as

\section{$\mathrm{E}=\rho \times \mathrm{g} \times \mathrm{Q} \times \mathrm{TDH} \quad \ldots$ (i)}

Where, $g$ is the acceleration due to gravity $\left(9.81 \mathrm{~m} / \mathrm{s}^{2}\right)$, $\mathrm{Q}$ is water discharge (in $\mathrm{m}^{3} / \mathrm{s}$ ), $\rho$ is specific water density, and TDH is the total dynamic head (m) is sum of static head (m) and friction losses (m).

Required input electrical energy from PV array

$$
\begin{aligned}
\mathrm{P} & =\mathrm{E} / \text { conversion efficiency (wire to water) } \\
& =\mathrm{E} / 0.266
\end{aligned}
$$

The volume of water discharge is obtained by

$\mathrm{Q}=\mathrm{E} /(\rho \times \mathrm{g} \times \mathrm{TDH})$

The overall efficiency $\left(\eta_{\mathrm{E}}\right)$ of solar photovoltaic water pumping system is given as

$\eta_{\mathrm{E}}=\left(\eta_{\mathrm{dS}} \times \eta_{\mathrm{P}}\right)$.

where, motor-pump system efficiency is given as $\eta_{\mathrm{ds}}$; $\eta_{\mathrm{p}}$ is PV array efficiency)

\section{B. Economic Analysis}

\section{Fundamentals of economic analysis:-}

In order to perform economic analysis of the system total cost of the project is to be known. The total cost includes expenditures to be acquired in various components of the system such as equipments, transportation, erection, construction and commissioning etc. The details of cost estimation include detailed economic overview of all the component of photovoltaic water pumping system and extra expenses during project installation, operation and maintenance. This details present effectively reasonable arrangement for further use.

Common techniques which generally used for economic assessment are-

(i) Payback Period: - It is the time which is required for getting the investment back from the gained benefits. It is calculated as

Payback Period $=$ (Investment cost) $/$ (Annual benefits obtained from the system)

(ii) Life Cycle Costs: - It is the total of all the expenses and benefits related with the pumping system over its lifetime or in period of analysis. It is expressed in terms of the Present worth (PW). For the system to be advantageous, the benefits must be more prominent than the expenses [23].

Calculation of the Present worth (PW)

$\mathrm{PW}=\mathrm{F} /(1+\mathrm{d})^{\mathrm{n}}$,

Where, F - Future value; d - Discount rate; $\mathrm{n}$ - Number of years which is expected to take place

For the purpose of the cost assessment: An irrigation system might be expected to comprise of six components; water source, power source, pump, storage tank (where required); water flow network; field application strategy for consideration.

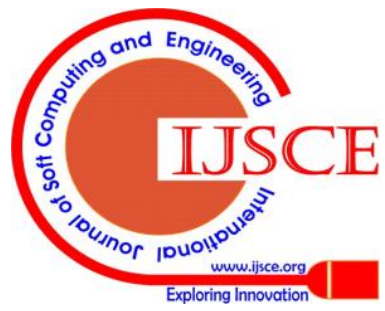


2. Cost estimation of practically reviewed system:-

(i) Investment Cost:-

Table 2 presents cost estimation of solar PV water pumping system

Table 2 Cost estimation of solar PV water pumping system

\begin{tabular}{|c|l|c|c|}
\hline S. N. & \multicolumn{1}{|c|}{ Description } & Qty. & Amount \\
\hline II. & $\begin{array}{l}\text { DC submersible water } \\
\text { pumping system of 5 } \\
\text { hp capacity }\end{array}$ & 1 & $\begin{array}{r}\text { Rs. 2,30,000 } \\
\text { (with subsidy) }\end{array}$ \\
\hline IV. & $\begin{array}{l}\text { Construction of storage } \\
\text { tanks }\end{array}$ & --- & Rs. 25,000 \\
\hline V. & Transportation & --- & Rs. 5,000 \\
\hline VI. & Miscellaneous & --- & Rs. 10,000 \\
\hline & Total & & \multicolumn{2}{|c|}{ Rs. 2,70,000 } \\
\hline
\end{tabular}

(i) Annual expenditure estimation:

Table 3 Annual expenditure estimation of solar PV water pumping system

\begin{tabular}{|c|l|c|}
\hline S. N & \multicolumn{1}{|c|}{ Description } & Amount \\
\hline I. & $\begin{array}{l}\text { Annual Depreciation of all } \\
\text { equipment (Replacement cost) }\end{array}$ & Rs. 5,000 \\
\hline II. & Repair and maintenance & Rs. 1,000 \\
\hline III. & Other expenses & Rs. 500 \\
\hline & Total & Rs. 6,500 \\
\hline
\end{tabular}

(ii) Payback period -

If diesel pump are used then suppose it is required to invest Rs.94335 as diesel cost. So, for calculation of payback period we will take this as annual benefits. To calculate investment cost of the system it is required to know life span of the system. The life span of the system depends on its components like PV modules, controller unit, pumping system etc. The life span of PV array, controller unit, and pumping system is around $20-25$ years, $10-12$ years and 8-10 years respectively. Overall average life span of the system can be taken 20 years with addition of maintenance \& replacement cost.

To calculate total investment cost including all expenditures, we will consider 20 years system life span. Total annual expenditure on system in 20 year life span is $20 \times 6,500=$ Rs. $1,30,000$

Total system cost estimation over life time =Rs. $270000+$ Rs. $130000=$ Rs. 4,00.000

Payback Period $=$ Rs. $((4,00,000) /(94,335))=4.24$ Year (approx. 4 year 3 months)

(iii) Present worth of the system-

If the life span of system - 20 year, discount rate- $10 \%$ and future value- Rs. 4, 00,000 then present worth is-

$\mathrm{PW}=\left(\right.$ Rs. $4,00,000 /(1+.10)^{20}=$ Rs. 59457.53

3. Cost comparison between solar and diesel water pump (without including other expenditures):-

(i). Solar Pump Option: 5 h.p. BLDC Motor Pump Set:-
Table 4 Cost estimation of solar water pumpset

\begin{tabular}{|l|l|}
\hline Solar Pump System Cost & Rs.5,00,000 \\
\hline Government Subsidy(Rs.54,000 per hp) & Rs.2,70,000 \\
\hline Other expenses & Rs.1,30,000 \\
\hline Total cost of system & Rs.4,00,000 \\
\hline Annual investment by user & Rs. 59,458 \\
\hline
\end{tabular}

(ii) Diesel Pump Set Option: 5 h.p. (Running for 5 hrs. /day for Equivalent Discharge)

Table 5 Cost estimation of diesel water pumpset

\begin{tabular}{|l|l|}
\hline Cost of diesel pumpset: & Rs. 70,000 \\
\hline Diesel consumption rate & 1.0 liters per hour \\
\hline Delivered diesel cost & 62 Rs. / liter \\
\hline Daily diesel pump usage & 5 hrs \\
\hline Annual average diesel cost & $\begin{array}{l}\text { Rs.94,335 (average 300 } \\
\text { days) }\end{array}$ \\
\hline
\end{tabular}

(iii). PV-Diesel Pump Cost Comparison (Cost per year):-

Table 6 Cost comparison between diesel and solar water pumpset

\begin{tabular}{|l|l|}
\hline Solar Pump Option:- Pay by user every year & Rs. 59,458 \\
\hline $\begin{array}{l}\text { Diesel Pump Set Option:-Average Diesel } \\
\text { cost per year }\end{array}$ & Rs. 94,335 \\
\hline
\end{tabular}

* This is approximate data used to show the difference and actual data may vary.

In past, usually diesel pump was the only option for water pumping in rural and undeveloped regions where there was no power grid connection available and water requirement was higher than what hand or foot pumps can deliver. When solar water pumping system became popular, scenario of water pumping became changed. There are various differences between the diesel and solar pumping system power sources as far as cost and reliability is concerned. Diesel pumps in general demands a lower initial cost but has a very high operation and maintenance cost whereas, Solar demands a higher first cost but very low ongoing operation and maintenance costs. In terms of cost and reliability, it is easy to keep a solar-powered system going than a diesel engine [24].

Published By:

Blue Eyes Intelligence Engineering

\& Sciences Publication

(C) Copyright: All rights reserved.

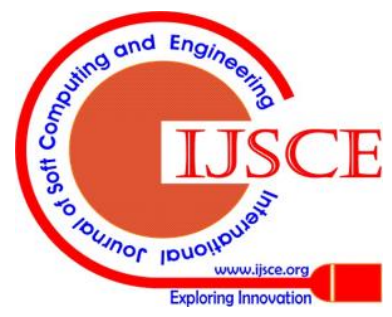




\section{Advantages, limitations and solutions of solar photovoltaic water pumping system}

Table 7 Advantages, limitations of solar water pumpset

\begin{tabular}{|c|c|}
\hline $\begin{array}{l}\text { Advantages of solar photovoltaic water } \\
\text { pumping system }\end{array}$ & Limitations of solar photovoltaic water pumping system \\
\hline - Sun light is freely available, so no fuel cost. & $\begin{array}{l}\text { - Solar water pumping is not reasonable where the } \\
\text { demand is high. }\end{array}$ \\
\hline - Electricity is not required. & $\begin{array}{l}\text { - The cost of the system is also a problem for poor farmer } \\
\text { to adopt this technology. }\end{array}$ \\
\hline - Operational durability is long. & - Proper technological promotion is limited. \\
\hline - It is dependable and Environment friendly. & $\begin{array}{l}\text { - The water yield of the solar-powered pumping system } \\
\text { changes as per the variation in sunlight. }\end{array}$ \\
\hline - Operation and Maintenance is easy. & $\begin{array}{l}\text { - To get the water in non-sunny days is a drawback of this } \\
\text { technology. }\end{array}$ \\
\hline - Sun light is freely available, so no fu & - Theft of solar PV modules is an issue in a few regions. \\
\hline
\end{tabular}

\section{Solutions}

- $\quad$ Energy storage system can be used to provide power supply during non-sunny days.

- Farmers should try to get the subsidy which is provided by government on solar water pumping system.

- Workshops should be organized by the government for promotion the technology among farmers.

- Daily or seasonal tracking of PV modules should be used to get more power from solar energy.

- To protect PV modules from theft, fence should be used around the place where system is installed.

D. Recent advancement in solar PV water pumping system

- $\quad$ Price of photovoltaic panel is decreasing day to day with technology advancement , due to this overall cost of the system has dropped.

- Smart controllers have developed; which helps to use power generated from PV panels in other applications during non- pumping hours.

- $\quad$ Researchers are developing PV modules with higher efficiency.

- $\quad$ Remote monitoring based pump controller has been designed, which help to control the system automatically.

- Advanced technology based automatic system has been developed to track the system

\section{CONCLUSION}

This study highlighted the technical and economical aspects of solar photovoltaic water pumping system. Practicability \& importance of solar photovoltaic water pump has been proved in the field of water pumping application. The solar PV water pumping system has become a solution for water pumping in remote locations where the electricity is not available. As per analysis it can be said that this is best method for water pumping which have higher life span with low maintenance. Economic analysis shows that solar water pumping system is a finest option as compared to diesel generator based water pumping system and it has lower payback period. The techno-economic analysis of this study gives the knowledge about head size effect on water output and technical \& economical assessment factors for photovoltaic water pumping system performance evaluation.
The use of renewable energy helps to minimize the global warming and become the basic requirement for the world to save the nature from pollutants of fossil fuels. In many places farmers faced problem due to inadequate availability of power for water pumping for their crops and due to this their annual income and life style became worse ,use of this solar PV pumping technology has proved as a great help to the farmers and has helped to strengthen our agriculture sector. This paper may facilitate researchers and interested learners to understand comparative techno-economic analysis of solar water pumping system.

\section{REFERENCES}

1. Meah K, Ula S, and Barrett S. 2006. Solar photovoltaic water pumping opportunities and challenges. Elsevier, Renewable and Sustainable Energy Reviews 12: 1162-1175.

2. Chandel S S, Naik M N and Chandel R.2015. Review of solar photovoltaic water pumping system technology for irrigation and community drinking water supplies. Elsevier, Renewable and Sustainable Energy Reviews 49: 1084-1099.

3. Abdullah S, Hossain A M, and Lixue W.2017. Solar Power Pumping in Agriculture: a Review of Recent Research. Juniper publishers, Agri Res \& Tech 4(3).

4. Pytlinski J T.1978. Solar energy installations for pumping irrigation water. Pergamon Press Ltd., Solar Energy 21: 255-262.

5. Meah K, Fletcher S, and Ula S.2008. Design optimization of photovoltaic powered water pumping systems. Elsevier, Energy Conversion and Management 47: 1449-1463.

6. Singh B and Mishra A. 2015. Utilization of Solar Energy for Driving a Water Pumping System. International Research Journal of Engineering and Technology (IRJET) 2(3)

7. Campana P E et al. 2016. Suitable and optimal locations for implementing photovoltaic water pumping systems for grassland irrigation in China. Elsevier, Applied Energy.

8. Odeh I, Yohanis Y G, and Norton B.2006. Economic viability of photovoltaic water pumping systems. Elsevier, Solar Energy 80: 850-860.

9. Lal S, Kumar P, and Rajora R.2013.Techno-economic analysis of solar photovoltaic based submersible water pumping system for rural areas of an Indian state Rajasthan. Science Journal of Energy Engineering 1: 1-4.

10. Braijnstein A and Kornfeld A.1981. Analysis of solar powered electric water pump. Pergamon Press Ltd. Solar Energy 27: 235-240.

11. Ghoneim A A. 2006. Design optimization of photovoltaic powered water pumping systems. Elsevier, Energy Conversion and Management 47: 1449-1463.

Published By:

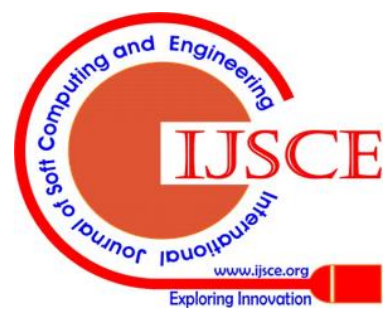

\& Sciences Publicatio

(C) Copyright: All rights reserved. 
12. Bakelli Y, Arab A H, and Azoui B.2011. Optimal sizing of photovoltaic pumping system with water tank storage using LPSP concept. Elsevier, Solar Energy 85: 288-294.

13. Badescu V.2001. Dynamic model of a complex system including PV cells, electric battery, electrical motor and water pump. Elsevier, Energy 28: 1165-1181.

14. Campana P E, Li H, Zhang J, Zhang R, Liu J, and Yan J. 2015. Economic optimization of photovoltaic water pumping systems for irrigation. Elsevier, Energy Conversion and Management 95: 32-41.

15. Falcon S, Li H, Zhang J, Zhang R, Liu J, and Yang J. 2015. Development of Solar Powered Water Pumping System. IJIRST -International Journal for Innovative Research in Science \& Technology 1(12): 2349-6010.

16. Kolhe M, Joshi J C, and Kothari D P. 2004. Performance Analysis of a Directly Coupled Photovoltaic Water-Pumping System. IEEE, Transactions on Energy Conversion 19(3).

17. Benghanem M, Daffallah K O, Alamri S N, and Joraid A A.2014. Effect of pumping head on solar water pumping system. Elsevier, Energy Conversion and Management 77: 334-339.

18. Mokeddem A et al. 2011. Performance of a directly-coupled PV water pumping system. Elsevier, Energy Conversion and Management 52: 3089-3095.

19. Gadekar S R, Midoun A, Kadri D, Hiadsi S, and Raja I A .2016 Review on Solar Water Pumping System. Present at ICRISEM, 2016.

20. Bolaños J C, Orozco W O, and Bhandari R.2014. Techno-Economic Feasibility Study of Solar and Wind Based Irrigation Systems in Northern Colombia. Published at Conference Proceedings Paper, World Sustainability Forum, 2014.

21. Lodha N K and Sudhakar K. 2013. Theoretical Design and Simulation Analysis of PV Based Pumping System for Domestic Applications in Bhopal, M.P. (India). International Journal of Science and Research (IJSR).

22. GSES India Sustainable Energy Pvt. ltd. 2015. Standalone Photovoltaic Systems Design \& Installation. System Design and Engineering Course Training Manual, $3^{\text {rd }}$ edition.

23. Kenna J J and Gillett B. 1985. Solar Water Pumping-A Handbook. London: Intermediate Technology Publications.

24. MNRE. 2015-16. Indicative Technical Specifications of Solar Deep well (submersible) Pumping Systems. Ministry of New and Renewable Energy, India.

\section{AUTHOR PROFILE}

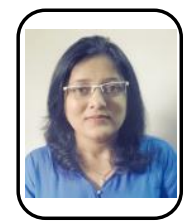

Dr. Rakhi Sharma is Associate Professor, Electrica Engineering in School of Engineering \& Technology, IGNOU, New Delhi ; She did her Ph.D. from IIT Delhi. Her main area of research interest is solar Technology, Solar photovoltaic (PV) Systems, Renewable Energy. She has many research publications in international journals of repute.

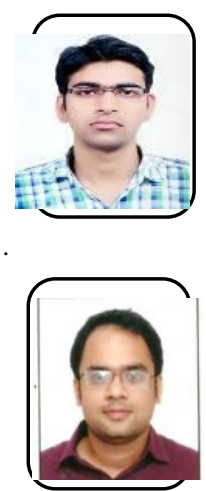

Mr Shivanshu Sharma is working in Uttar Pradesh Power Corporation Limited, Delhi, India . He did his M.Tech from University of Kota, Rajasthan. He is perusing Ph.D. and his area of research interest is renewable energy applications. He has research publication in international journal.

Mr. Shashank Sharma is a Assistant Professor in MITS Gwalior , M.P. He did his B.Tech from University Institute of Technology, RGPV ,Bhopal and M.Tech from MANIT Bhopal. He is involved in several research activities and also has keen interest in mathematical computation in engineering applications.

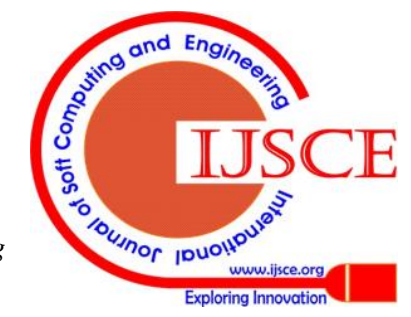

